\title{
POLA BUDAYA TERHADAP MAKANAN, MASALAH BUDAYA TERHADAP MAKANAN DAN GIZI, SISTIM BUDAYA TERHADAP MAKANAN, SOLUSI MENGATASI MASALAH BUDAYA DAN MAKANAN
}

\author{
Fitria Amelia ( 70200121110 ) \\ KSM D \\ Prodi kesehatan masyarakat \\ Fakultas kedokteran dan ilmu kesehatan \\ Universitas Islam negeri Alauddin Makassar
}

\section{POLA BUDAYA TERHADAP MAKANAN}

Banyak orang berpendapat bahwa kebudayaan merupakan hasil cipta mannsia,tetapi dalam hal ini yang dimaksud konsep kebudayaan adalah nilai, sikap,kebiasaan yang dipelajari dan diperoleh sejak anak masih kecil. Kebudyaan adalah suatu rangkaian peraturan-peraturan yang mengatur tingkah laku anggota masyarakat. Di dalam usha mempelajari kebiasan makan, slake kita harus memahami karakteristik kebudayaan dan hubungangan dari karakteristikkarakteristik tersebut yang berguna untuk melakukan suatu perobahan.

Kebudayaan adalah seluruh sistim gagasan dan ras, tindakan serta karya yang dihasilkan manusia dalam kehidupan bermasyarakat yang dijadikan miliknya dengan belajar (Koentjaraningrat, 2004). Selanjutnya dikatakan juga bahwa wujud dari budaya atau kebudayaan dapat berupa benda-benda fisik, sistim tingkah laku dan tindakan yang terpola/sistim sosial, sistim gagasan atau adat-istiadat serta kepribadian atau nilai-nilai budaya.

Berdasarkan atas batasan demikian maka dapat dikatakan bahwa makanan atau kebiasaan makan merupakan suatu produk budaya yang berhubungan dengan sistim tingkah laku dan tindakan yang terpola (sistim sosial) dari suatu komonitas masyarakat tertentu. Sedangkan makanan yang merupakan produk pangan sangat tergantung dari faktor pertanian di daerah tersebut dan merupakan produk dari budaya juga.

Dengan demikian pengaruh budaya terhadap pangan atau makanan sangat tergantung kepada sistim sosial kemasyarakatan dan merupakan hak asasi yang paling dasar, maka pangan/makanan harus berada di dalam kendali kebudayaan itu sendiri. Beberapa pengaruh budaya terhadap pangan/makanan adalah: Adanya bermacam jenis menu makanan dari setiap 
komunitas etnis masyarakat dalam mengolah suatu jenis hidangan makanan karena perbedaan bahan dasar/adonan dalam proses pembuatan; contoh: orang Jawa ada jenis menu makanan berasal dari kedele, orang Timor jenis menu makanan lebih banyak berasal dari jagung dan orang Ambon jenis menu makanan berasal dari sagu. Demikian juga orang Sulawesi menu makanan beragam yakni berasal dari beras, jagung dan sagu.

Adanya perbedaan pola makan/konsumsi/makanan pokok dari setiap suku/etnis ; Contoh : orang Timor pola makan lebih kepada jagung, orang Jawa pola makan lebih kepada beras. Adanya perbedaan cita-rasa, aroma, warna dan bentuk fisik makanan dari setiap sukuetnis; Contoh: makanan orang Padang cita rasanya pedis, orang Jawa makananya manis dan orang Timor makanannya selalu yang asin. Adanya bermacam jenis nama dari makanan tersebut atau makanan khas berbeda untuk setiap daerah; contoh: Soto Makasar berasal dari daerah Makasar-Sulawesi Selatan, Jagung "Bose" dari daerah Timor-Nusa Tenggara Timur, contoh lain dari daerah Maluku adalah sagu lempe yang biasa digunakan untuk snack dan lebih umum biasa digunakan sebagai behan oleh-oleh.

Kemungkinan faktor sosial budaya yang menyangkut tradisi sosial misalnya selamatan atau kenduri yang menyertai berbagai ritual atau upacara adat yang terjadi hampir sepanjang tahun selalu diselenggarakan baik oleh suatu keluarga maupun secara komunal (kelompok). Selain

itu adanya budaya atau sistem weh-wehan atau saling memberi makanan sesama warga merupakan bentuk distribusi makanan dalam kehidupan masyarakat di wilayah kabupaten Bantul sehingga budaya semacam itu ikut menunjang perbaikan gizi keluarga, termasuk anakanak dalam keluarga bersangkutan.

Faktor non medis dalam kaitan ini menyangkut pembagian dan pemerataan makanan melalui tradisi selamatan atau kenduri yang dilandasi sistem nilai budaya yang masih dipegang kuat dan dianut oleh masyarakat. Sistem nilai budaya terdiri dari konsepsi-konsepsi, yang hidup dalam alam pikiran sebagian besar warga masyarakat, mengenai hal-hal yang harus mereka anggap amat bernilai dalam hidup.

Sebagai phenomena sosiarl dan budaya makanan tidaklah hanya sebagai produk organik dengan kualitas bio-kimia yang dapat digunakan untuk manusia tetapi mekanan diartikan juga dalam hubungannya dengan kebudayaan karena sebagai bahan makanan yang akan dikonsumsikan memerlukan pengesahan dari kebudayaan untuk dapat diterima. Banyak manusia yang meskipun dalam keadaan lapar, tidak menggunakan semua bahan nakanan yang 
bergizi sebagai makanan karena alasan agama tabu, kepercayaan. oleh karena itu perlu dibedakan anatara pengertian nutsi dan makanan.

Foster (1978), menyatakan bahwa nutrisi adalah konsep bio-kimia suatu bahan makanan yang mengandung gizi dan berguna untuk memelihara kesehatan bagi organisme yang mengkonsumsinya . sedangkan makanan dalam konsep kebudayaan adalah penyataan yang menjelaskan bahwa bahan ini adalah cocok untuk gizi kita. Jadi bahwa di dalam konsep kebudayaan memasukkan unsur nilai,kepercayaan sehingga timbulah penggolongan apa yang dimaksud dengan makanan dan yang bukan makanan. Hal ini yang menyebabkan sulitnya meyakinkan masyarakat untuk merubah kebiasaan makan.

\section{MASALAH BUDAYA TERHADAP MAKANAN DAN GIZI}

Mencermati akan adanya budaya, kebiasaan dan sistim sosial masyarakat terhadap makanan seperti pola makan, tabu atau pantangan, gaya hidup, gengsi dalam mengkonsumsi jenis bahan makanan tertentu, ataupun prestise dari bahan makanan tersebut yang sering terjadi di kalangan masyarakat apabila keadaan tersebut berlangsung lama dan mereka juga belum memahami secara baik tentang pentingnya faktor gizi dalam mengkonsumsi makanan maka tidak mungkin dapat berakibat timbulnya masalah gizi atau gizi salah (Malnutrition).

Lebih lanjut dijelaskan oleh Suhardjo, 1996 bahwa jika kalangan masyarakat yang terkena dampak dari sistim sosial atau budaya makan itu berasal dari golongan individuindividu yang termasuk rawan gizi seperti ibu hamil, ibu menyusui, bayi dan anak-anak balita serta orang lanjut usia maka kondisi ini akan lebih rentan terhadap timbulnya masalah gizi kurang.

Gizi salah (Malnutrition) dapat didefenisikan sebagai keadaan sakit atau penyakit yang disebabkan oleh kekurangan relative atau mutlak dan kelebihan satu atau lebih zat-zat makanan esensial yang berguna dalam tubuh manusia. Menurut bentuknya, gizi salah diklasifikasikan oleh (Supariasa et al., 2002) sebagai berikut :

1. Gizi kurang (undernutrition), kondisi ini sebagai akibat dari konsumsi makanan yang tidak memadai jumlahnya pada kurun waktu cukup lama.

Contoh : Kekurangan Energi Protein (KEP) dapat menyebabkan penyakit marasmus dan kwashiorkor.

2. Gizi lebih (Overnutrition), keadaan ini diakibatkan oleh konsumsi makanan yang berlebihan untuk jangka waktu yang cukup lama sebagai contoh kegemukan 
3. Kurang Gizi spesifik (Specific Deficiency): keadaan ini disebabkan oleh kekurangan relative atau mutlak pada zat-zat makanan tertentu.

Contohnya : kekurangan vitamin A yang dapat menyebabkan penyakit xeropthalmia dan Gangguan Akibat Kekurangan Iodium (GAKI) yang dapat menyebabkan penyakit gondok.

4. Gizi tak seimbang (inbalance): Kondisi yang merupakan akibat dari tidak seimbangnya jumlah antara zat-zat makanan esensial, dengan atau tanpa kekurangan zat makanan tertentu. Contoh; gangguan keseimbangan tubuh,sering loyo dll.

\section{SISTIM BUDAYA TERHADAP MAKANAN}

Berbagai sistim budaya memberikan peranan dan nilai yang berbeda-beda terhadap makanan, misalnya bahan-bahan makanan tertentu oleh suatu budaya masyarakat dapat dianggap tabu atau bersifat pantangan untuk dikonsumsi karena alasan sakral tertentu atau sistim budaya yang terkait didalamnya. Disamping itu ada jenis makanan tertentu yang di nilai dari segi ekonomi maupun sosial sangat tinggi eksistensinya tetapi karena mempunyai peranan yang penting dalam hidangan makanan pada sesuatu perayaan yang berkaitan dengan kepercayaan masyarakat tertentu maka hidangan makanan itu tidak diperbolehkan untuk dikonsumsinya bagi golongan masyarakat tersebut.

Anggapan lain yang muncul dari sistim budaya seperti dalam mengkonsumsi hidangan makanan didalam keluarga, biasanya sang ayah sebagai kepala keluarga akan diprioritaskan mengkonsumsi lebih banyak dan pada bagian-bagian makanan yang mengandung nilai cita rasa tinggi. Sedangkan anggota keluarga lainnya seperti sang ibu dan anak-anak mengkonsumsi pada bagian-bagian hidangan makanan yang secara cita-rasa maupun fisiknya rendah.

Sebagai contoh pada sistim budaya masyarakat di Timor yaitu: apabila dihidangkan makanan daging ayam, maka sang ayah akan mendapat bagian paha atau dada sedangkan sang ibu dan anak-anak akan mendapat bagian sayap atau lainnya. Hal ini menurut (Suhardjo, 1996) dapat menimbulkan distribusi konsumsi pangan yang tidak baik atau maldistribution diantara keluarga apalagi pengetahuan gizi belum dipahami oleh keluarga.

Kasus lain yang berhubungan dengan sistim budaya adalah sering terjadi juga pada masyarakat di perkotaan yang mempunyai gaya hidup budaya dengan tingkat kesibukan yang tinggi karena alasan pekerjaan. Contohnya; pada ibu-ibu di daerah perkotaan yang kurang dan tidak sering menyusui bayinya dengan Air Susu Ibu (ASI) setelah melahirkan tetapi hanya diberikan formula susu bayi instant. Padahal kita tahu bahwa ASI sangat penting untuk 
pertumbuhan dan perkembangan fisik bayi. Selanjutnya gaya hidup mereka yang berasal dari golongan ekonomi atas (masyarakat elite kota), dalam hal makanan sering mengkonsumsi makanan yang berasal dari produk luar negeri atau makanan instant lainnya karena soal "gengsi".

Sedangkan makanan lokal kita hanya dikonsumsi oleh mereka yang berasal dari golongan ekonomi menengah ke bawah karena ada anggapan bahwa makanan dari luar negeri kaya akan nilai gizi protein dan makanan instant lebih praktis untuk dikonsumsi sedangkan makanan lokal kita nilai gizinya lebih kepada karbohidrat. Sehubungan dengan soal gengsi maka ada kebiasaan masyarakat di Timor jika ada kunjungan tamu ke rumahnya maka tamu tersebut selalu di hidangkan dengan makanan yang berasal dari beras walaupun kesehariannya mereka selalu mengkonsumsi jagung, ubi kayu/singkong dan makanan lokal lainnya sehingga beras atau nasi telah dianggap sebagai suatu citra bahan makanan yang mempunyai nilai prestise" yang tinggi. Citra beras/nasi dibangun sebegitu kuatnya oleh masyarakat di Timor sehingga kondisi ini telah mempengaruhi sendi-sendi sosial budaya sedangkan pandangan mereka terhadap pangan di luar beras di tempatkan sebagai symbol lapisan masyarakat paling rendah.

\section{SOLUSI MENGATASI MASALAH BUDAYA DAN MAKANAN}

Masalah budaya dan makanan kita ketahui dapat menyebabkan masalah gizi yang berdampak pada kesehatan tubuh manusia, sehingga perlu secara cermat untuk memberdayakan masyarakat lokal dengan kearifan dan kecerdasan lokal (local wisdom and local genius) disamping terus melaksanakan penyuluhan gizi sebagai alternative mengatasi masalah budaya dan makanan.

Pendekatan yang paling utama adalah melalui perbaikan struktur sosial masyarakat tentang pandangan mereka terhadap bahan makanan walaupun lokal tetapi kaya akan nilai gizi. Langkah-langkah yang ditempuh seperti:

1. Perbaikan gizi keluarga dengan melakukan lomba menyiapkan hidangan makanan non beras (kasus budaya Timor),

2. Perbaikan budaya masyarakat dengan pengaruh utama gender terutama di tingkat keluarga. 
3. Memperluas areal pertanian dengan menanam berbagai komoditi yang mempunyai nilai gizi tinggi sebagai bahan pangan/makanan seperti kedelai (kasus budaya Jawa).

4. Pemberian makanan tambahan yang bernilai gizi bagi anak-anak balita dan orang lanjut usia.

5. Penyuluhan gizi terpadu dan konsultasi gizi bagi masyarakat.

6. Melakukan pengkajian/penelitian dan riset untuk melihat pengaruh budaya terhadap makanan itu sendiri dengan berbagai implikasi yang terkait didalamnya. 


\section{DAFTAR PUSTAKA}

Banudi la, Imanuddin. (2017). Sosiologi dan antropologi gizi. Kendari: forum ilmiah kesehatan

Ibrahim Anwar Irviani, Syamsul Alam, Andi Syamsiah Adha, Yusma Indah Jayadi, Muhammad Fadlan. (2021). " Hubungan Sosial Budaya Dengan Kejadian Stunting Pada Balita Usia 24-59 Bulan Di Desa Bone-Bone Kecamatan Baraka Kabupaten Enrekang Tahun 2020" dalam Al Gizzai: Public Health Nutrition Journal (hlm. 16-26).

Kasnodiharjo, tri Juni angkasawati. (2013). “ Nilai-nilai budaya yang mendasari pemerataan makanan yang dapat menunjang gizi keluarga “. Jakarta: Pusat Teknologi Intervensi Kesehatan Masyarakat J1. Percetakan Negara No. 29 (Vol. 42, No. 1, 2014: 59 - 70) 